\title{
A Study on the Decorative Design of Qinzhou Nixing Pottery
}

\author{
Shao Qiang Ning1,Juan Xiu Hou2 \\ ${ }^{1}$ Guangxi Normal University School of Design, Guilin, Guangxi, China, \\ 723924855@qq.com, \\ ${ }^{2}$ Guangxi Normal University School of Design, Guilin, Guangxi, China, \\ 170099678@qq.com,
}

\begin{abstract}
As one of top-four potteries in China, Qinzhou Nixing pottery has a long history and unique characteristics. In the aspect of its production processes, through polishing and fantastic fambe Nixing pottery is full of antique flavor. However, there are many aspects to be improved in the development of Nixing pottery. This paper through mainly analyzing the current situation of the decorative design of Nixing pottery summarizes the problems encountered during the development, and, on the basis of the problems, proposes suggestions that the trends of the design of Nixing pottery should cohere with the spirit of the age, good taste and merchantability.
\end{abstract}

Keywords: Nixing pottery, decorative design,current situation,trends

\section{Introduction}

The scientific name of Qinzhou Nixing pottery is Zini pottery. Nixing pottery originated in the Tang Dynasty, flourished during the reign of Emperor Xianfeng of Qing Dynasty, and has a long history of 1270 years. It won the gold medal at the 1957 Panama Pacific International Exposition held in San Francisco. During the later development, Nixing pottery won more than 40 awards at international and national exhibitions; moreover more than 20 national museums have the collection of artworks made of Nixing pottery. Nixing pottery has a promised future and will also face the fierce competition within the industry. Nixing pottery must innovate continuously in every aspect, and improve its quality to achieve better development. The decorative design of Nixing pottery has unique value in appreciation in terms of the shape. And it is a means to beautify Nixing pottery, a way to give people visual stimulation, and is often treated as a kind of symbol or an important tool for socio-cultural communication.

\section{The Current Situation of the Deco- rative Design of Nixing Pottery}

Currently, the major products of Nixing pottery are tea sets, flowerpots, vases, utensils, tripod cauldrons, stationery, ornaments and so forth. The decoration theme of pottery is determined by its function, and mainly embodies the spiritual content of the pottery. Now the main technique for decoration is a combination of calligraphy and painting, and most of the themes are wishes for happiness and better future. The themes of Nixing pottery can be roughly classified into three categories, i.e. calligraphy, figures and landscape, and plants and animals, and a lot of shapes and themes are blended with 
elements such as bronze drums with characteristics of Guangxi folk culture, Zhuang brocade, and the fresco of Guangxi Flower Mountain, showing distinct regional features. Basically the decoration processes of Nixing pottery adopt flat carving, relief carving, hollowing and kneading, mosaic, filling and other techniques. There are also some modern pottery works which demonstrate the visual beauty through their own unique styling.

For the decoration of different utensils, the usage of decorative themes of Nixing pottery have flexibility. There are no special rules that require certain themes must be applied to certain kinds of utensils, but the themes are chosen in accordance with the shape or the environment where the utensils will be used. The decoration of Nixing pottery, by skillfully using the space of pottery, fully shows the composition and content of the theme and perfectly combines the shapes of pottery. According to its usage, popular decorative themes are classified as shown in table1:

\begin{tabular}{|c|c|c|}
\hline $\begin{array}{l}\text { decorative } \\
\text { theme }\end{array}$ & content & usage \\
\hline $\begin{array}{l}\text { figures and allu- } \\
\text { sions }\end{array}$ & $\begin{array}{l}\text { beautiful ladies, the image of Bud- } \\
\text { dha, working people, the image of } \\
\text { the greats, smiling imperial concu- } \\
\text { bines }\end{array}$ & $\begin{array}{l}\text { Small ornaments, tea sets, } \\
\text { large vases }\end{array}$ \\
\hline $\begin{array}{l}\text { Landscape } \\
\text { paintings }\end{array}$ & $\begin{array}{l}\text { Most are selected in The Jiezi } \\
\text { Garden or classic landscape paintings } \\
\text { in Tang, Song, Yuan, and Ming Dyn- } \\
\text { asty. }\end{array}$ & $\begin{array}{l}\text { Large vases, tea sets, small } \\
\text { ornaments, and stationery, etc }\end{array}$ \\
\hline calligraphy & $\begin{array}{l}\text { regular script, Zhuanke (seal cut- } \\
\text { ting), official script, Chinese running } \\
\text { script, inscriptions on ancient bronze } \\
\text { objects, etc. }\end{array}$ & $\begin{array}{l}\text { commonly used in various } \\
\text { types of pottery products }\end{array}$ \\
\hline $\begin{array}{l}\text { Flowers and } \\
\text { birds }\end{array}$ & $\begin{array}{l}\text { plum blossom, orchid, bamboo, } \\
\text { chrysanthemum, pine, lotus, peony, } \\
\text { magpie, and crane, etc. }\end{array}$ & $\begin{array}{l}\text { Tea sets, small ornaments, } \\
\text { flower pots, stationery, etc. }\end{array}$ \\
\hline $\begin{array}{l}\text { Auspicious an- } \\
\text { imals }\end{array}$ & $\begin{array}{l}\text { loong (Chinese dragon), phoenix, } \\
\text { tortoise, tiger, and horse, etc. }\end{array}$ & $\begin{array}{l}\text { large vases, small ornaments, } \\
\text { tripod cauldrons, etc. }\end{array}$ \\
\hline $\begin{array}{l}\text { Geometric } \\
\text { drawings }\end{array}$ & $\begin{array}{l}\text { Fret, Ruyi pattern, ripples, and } \\
\text { diamond pattern, etc. }\end{array}$ & $\begin{array}{l}\text { commonly used in various } \\
\text { types of pottery products }\end{array}$ \\
\hline $\begin{array}{lr}\text { Unique } & \text { ele- } \\
\text { ments } & \text { from } \\
\text { Guangxi } & \text { ethnic } \\
\text { culture } & \end{array}$ & $\begin{array}{l}\text { Zhuang brocade, the fresco of } \\
\text { Guangxi Flower Mountain, bronze } \\
\text { drums, and colorful silk balls, etc. }\end{array}$ & $\begin{array}{c}\text { ea sets, large vases, tripod } \\
\text { cauldrons, small ornaments, etc. }\end{array}$ \\
\hline $\begin{array}{l}\text { For the memori- } \\
\text { al }\end{array}$ & $\begin{array}{l}\text { the image of the greats' heads, } \\
\text { some representative deeds }\end{array}$ & $\begin{array}{l}\text { large vases, small orna- } \\
\text { ments, and tea sets, etc. }\end{array}$ \\
\hline
\end{tabular}

Table.1: classification of the decorative themesof Qinzhou Nixing pottery

Note: Because of the variety of themes, this table only presents common classification. For example, elements like lucky clouds, fish, dolphins, gourds, and Chinese junks, etc. are also frequently used in the design of Nixing pottery. The typical 
themes about the figures, landscapes, characters, flowers and birds, auspicious animals, ethnic elements are shown in( Figure 1):

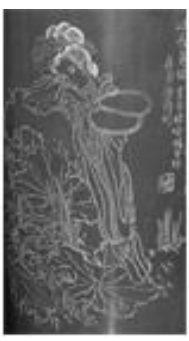

Fig. 1: Figures,

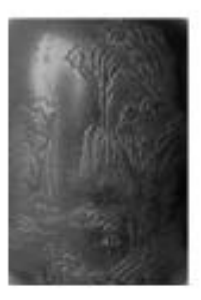

landscapes,

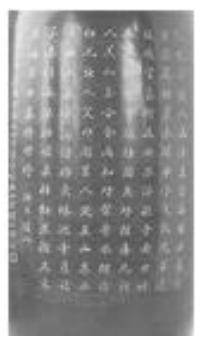

characters, flow
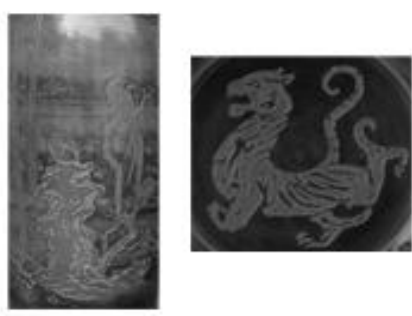

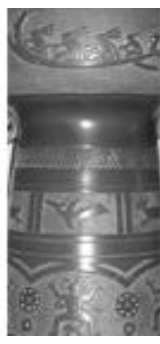

ethnic elements.
The main feature of Qinzhou Nixing pottery is that it can be unglazed, for the clay itself has a unique decorative effect unmatched by other famous potteries. Its fambe can be called a wonder in China. The fambe is purely accidental phenomenon, and not man-made. Due to the mineral content of clay, kiln temperature, firing atmosphere, and variation of the kiln location and other subtle changes, then under certain conditions, when the furnace temperature raises above the critical point, i.e. 1200 degree, a special incidental phenomenon, the fambe of pottery body, that the clay first oxidized then dioxides will happen [1]. After being burnt, the green ware will vaguely show purple, dark green, livid, bronze, maroon, yellow and other colors or texture changes. Then after further polishing, these identical features will appear (Figure 2). Through subsequent carving and decoration, profound artistic conception will be constituted, which can bring people endless imagination and exude antique charm. Such unmatched quality and feature have high appreciation and collection value.

Apart from the unique fambe of Nixing pottery, what is worth

mentioning is one of its decorative themes--calligraphy. Calligraphy can fully express personal integrity and temperament, which can express the artistic effect that paintings can not convey. The calligraphy style of Nixing pottery is dominated by regular script, and generally the main contents are mottos, poetries, and the Analects. These words are not mimeographed to the pottery in advance but are directly engraved on the pottery with knife instead of brush. The carving artistry is so sophisticated and unadorned that the pottery is full of humanistic flavor and intimacy created by pure craftsmanship. And only the craftsmen with calligraphy skills can master this technology. Character engraving is an important carrier of calligraphy art and information. The integration of characters and other decorations can diversify the decorative style of pottery. As the government attaches more importance to calligraphy, enthusiasm for calligraphy is triggered. People also begin to show more interests in calligraphy, and the engraving gradually becomes one of the major decorative themes of Nixing pottery.
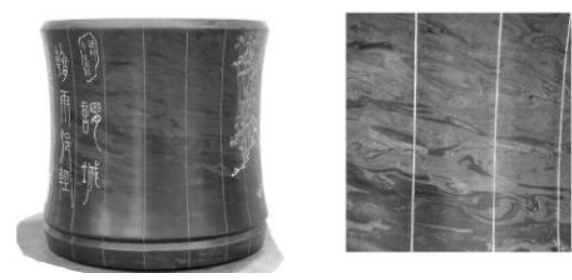

Fig. 2: ceramic products 
Currently, the development of Yixing Zisha pottery is the best among the topfour potteries in China's market. The decorative theme of Yixing Zisha pottery are various, such as all kinds of fruits and vegetables, different types of graphic design, folk culture, animals and plants, tourist attractions, calligraphy and paintings, poetries, commemorative materials, and themes adopted from relevant arts and crafts. Its decorative themes and techniques are very diverse; the product shape and decoration have reached a high degree of integration. The design of Zisha teapot meets the need of making tea and brings customers visual aesthetic experience as well. As China's top-four potteries, both Nixing pottery and Yixing pottery share many similarities as well as differ greatly in the aspects of decorative design. Since auspicious culture is greatly valued in the world, it has a profound impact on the creation of ceramic. Both Nixing pottery and Zisha teapot express the auspicious meaning through decorative themes or shapes. And this trend has never stopped; moreover it becomes more and more prosperous. The fambe of Nixing pottery is its natural decoration, and endows Nixing pottery with mysterious and unique characteristics. Furthermore, wide use of local ethnic elements plays a good role in the heritage of local culture. As for Yixing Zisha pottery, the decorative types of Zisha teapots are rich in species; elements from nature and life are well used in design, which makes the products more customer-friendly, brings lots of fun, and further meets the demand of modern aesthetic.

\section{Problems in the Development of Nixing Pottery Decorative Design}

\subsection{The lack of talents results in the lack of innovation in decoration and design}

Currently, most staffs who work in design and production of Nixing pottery are getting on years. And workers of throwing and carving are in urgent need. In the entire productions area of Nixing pottery, craftsman can be counted on fingers. The training is on the basis of traditional master-prentice mode. Although a few universities offer pottery-related courses, those who really work in Nixing pottery area are scarce because of low wage. Furthermore, with the separation of theory and practice and the lack of cultural identity, designers are always partial in the knowledge, skills and emotional aspects. This series of problems are the main reasons that lead to the scarcity of originality in the decorative design and the prevailing imitation. Innovation is an essential ability for pottery designers. Extensive knowledge, rational thinking ability, dexterity, rich emotion and fantastic imagination are the premise for designers to promote Nixing pottery decoration development. How to train and retain talents is the key issue for Nixing pottery industry to address. Nixing pottery industry must take measures, such as putting a high value on pottery education,strengthening school-enterprise cooperation, promoting pottery culture, enhancing people's awareness and emotion to Nixing pottery and establishing a system to encourage innovation.

\subsection{Backward Technologies and Equipments as well as Imperfect Business Management}

According to the survey, most Nixing pottery productions still adopt traditional production equipments with relatively 
low efficiency and backward skills. Firstly, Nixing pottery industry is a combination of technique and art. Nowadays, with ever-changing techniques and market demands, industrialization of Nixing pottery production must keep up with the pace of advanced techniques. Only by advanced crafts can the industry be promoted substantially. With the introduction of new technologies and equipments as well as the development of new crafts and products, the statue quo of single products and the lack of creativity can be disrupted. Secondly, the industry's relevant managers lack the pottery-related designing knowledge. Nixing pottery industry is short of a specific sound management system in terms of decorative design. The staff fail to manage and protect decorative patterns and drawings properly. Decorative patterns and styles are somewhat updated in every period. Companies should keep the used decorative patterns in paper and electronic archives, which is convenient to consult and produce in the future as well as of help to accumulate and form pottery decorative culture. Furthermore, in the process of management, the working staff, such as the throwing, the carving and other workers, can be trained and learn to appreciate excellent pottery products from home and abroad. Encouraging all workers to participate in the design with appropriate incentives and rewards can help to improve workers' enthusiasm.

\section{The Development Trends of Nixing Pottery Decorative Design}

As unglazed pottery products, the shape of Nixing pottery directly determines its basic form, while the decoration also relies on the shape to demonstrate the implication of its own. After all, its shape can not express everything. Sometimes, decoration can express contents and contexts more vividly and perfectly. In the future development of Nixing pottery industrialization, decorative design should not only develop various kinds of products with creativity and high quality, but also invigorate all aspects.

\subsection{Epochal Character of Decorative Design}

With the social development and the increasing social productive forces, people's horizons are also broadened gradually and the demands for aesthetic goods are on the rise. Although Nixing pottery design enjoys ancient charm, it lacks certain novelty. It inevitably becomes embarrassing for it focuses on ancient flavor and confines to the ancient style. Pottery productions in different periods possess their own artistic styles and embody different spirits of the times. As a geographical indication, Nixing pottery advocates traditions that are neither stereotypes nor copies without creativity, but combine with the features of the age and pass on contemporary information and spirituality. From the prospective of long-term development of Nixing pottery culture, the integration of creative design, cultural ideas and the era meets aesthetic demands.

Decorative themes of Nixing pottery root in traditional culture, and its contents and forms should be more abundant. We must analyze the current living environment and the way of life, observe tangent things as well as extract the decorative elements to innovate. The designs will not only keep pace with life and the times, but also be familiar to people. (Figure 3) This existing ceramic is named" Rise", which is derived from 

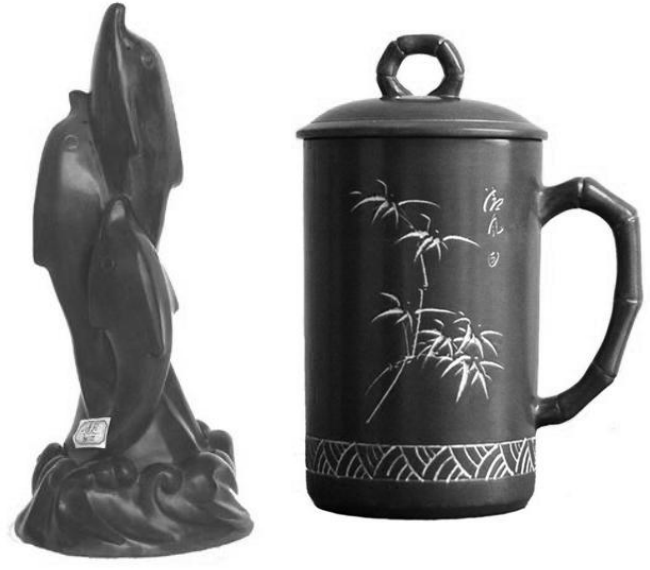

Fig.3: Rise

Fig.4: bamboo joints cup

the local dolphin element. Qinzhou is known as the hometown of dolphins, and this ceramic combines three cute dolphins' shape in a well-proportioned way. Three dolphins are climbing up, indicating an emerging spiritual strength with a far-reaching meaning and an appealing design. And the second piece is a pottery cup named "Bamboo joints cup" (Figure 4). The bamboo is a symbol of personal integrity and a scuttling metaphor for the strong character and the indomitable spirit. Cup body and lid are decorated by bamboo image and the pattern of bamboo joint. These works embody the contemporary spirits. Nixing pottery can develop in this direction to enrich the design of products and to enhance its spiritual strength as well.

\subsection{The Taste of Decorative Design}

Chinese craftsman Xu Xiutang believes that appreciation for Zisha teapot should understand truth and enjoy the fun. Zisha ceramic used to be "literati craft". Zisha teapot is popular for its practical function and convenience of making tea. When pouring water and tasting tea, they are playing with the Zisha teapot whose loveliness consists in "truth" and "fun". There- fore, Zisha teapot is a ceramic of superb quality. The so-called fun is the combination of emotion and interest. With the rapid economic and social development, people are faced with a wide variety of competitions and pressure in their life and work. At the same time, in the face of high-tech, people also require emotional compensations. The keys to promote Nixing pottery development lie in increasing fun of Nixing pottery for pleasing the public, enriching its products for breaking the monotony, and encouraging innovations in decorative themes, which are more urgent needs of consumers.

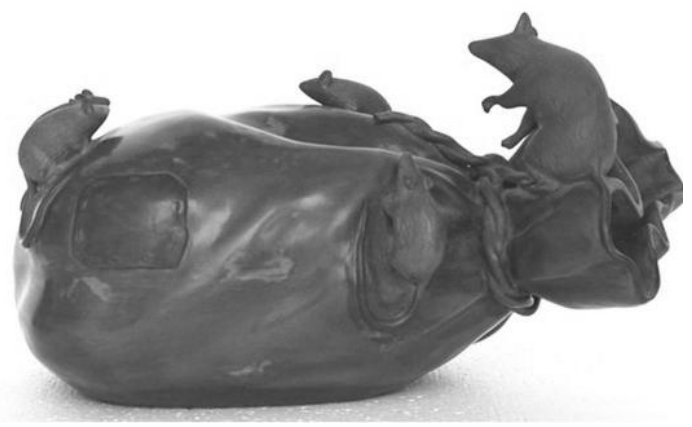

Fig.5: five children

The real value of the fun is reflected by participation and enjoyment of the audience. The shape of Nixing pottery can increase its interest. This ceramic, named "five children", constitutes a scene that five cute playful mice climbing up the bag and expresses an auspicious atmosphere. A patch on the bag gives the audience a warm novelty (Figure 5). Furthermore, in decorative design, Nixing pottery can design a variety of sets of products, such as couples sets, mother and children sets, family sets and other forms of cup products. In addition, through a combination of different parts to put the whole set of products together, suites products can show various effects. This variable design not only provides users with new experience, but also stimulates the users' imagination, thus it breaks 
product invariance. Such products have plasticity, playability, allowing consumers to participate in and adding products fun. Meanwhile, drawing humor and live pictures on green ware can attract consumers' attention and enhance the visual impacts. More surprises can be brought to consumers by absorbing art essence from porcelain, colored pottery, bronzes, wood carvings, ivory carvings and other crafts to enrich the decorations.

\subsection{Merchantability of Decorative De- sign}

Nowadays, Nixing pottery has formed a degree of industrialization. It is undeniable that profitable business is a necessary leverage for entire enterprise to operate normally. How to make better products is a thought-provoking question for us to sell products quickly and smoothly. Owning to different living spaces and environments as well as age and gender, aesthetic needs and decoration understanding are very different. Like the same clothes, in the eyes of different people, will produce various visual effects that may be endorsement or rejection. Therefore, it also determines that Nixing pottery decorative themes should be targeted. For different groups of consumers and in different occasions, decorative themes must meet their different needs and be in line with the public's aesthetic, so that it can better adapt to sale circumstance.

Nixing pottery decorative themes are mostly derived from poetries and the local ethnic elements. The styles are relatively simple and the products are not novel, which are important factors affecting sales. As a kind of commodity, as long as Nixing pottery products are accepted and recognized by customers, they can be sold successfully. Traditional specialties themes of geographical indications imply local history and culture, but people from other regions do not recog- nize or understand. Those themes are like greenhouse flowers suddenly come to the Northeast snowfield and lose the possibility of survival. Now, a lot of domestic design works are not accepted in the international arena, for these works bear too many complicated national characteristics. In a multicultural context of Nixing pottery decorative design, what we first need to do is to ensure our cultural consciousness. Based on improving cognitive ability and comprehension of traditional culture, we should learn more foreign outstanding crafts, find and understand ethnic elements and symbols created by other nations, analyze fashionable styles, popular varieties, local culture, customs and living standards, seize effective demands and combine national characteristics with modernity to produce accepted products. Only in this way can Nixing pottery achieve sustainable development in the market.

\section{Conclusion}

At the present stage, with relatively simple style and the lack of new ideas and fun, the design of Nixing pottery weakens the visual impact and is unable to meet the needs of the modern aesthetic. In view of this point, designers must master traditional techniques of Nixing pottery, break the status quo that confines to traditional ethnic elements and try to make a breakthrough in decorative contents, creativity and style diversification. Nixing pottery industry must absorb many nutrients, use them properly and update timely as well as enrich and develop its traditions and personality. These measures will not degrade the status of national culture, but will make the national culture and spirit more dynamic, more mature and more perfect. That Nixing pottery industry can thrive till today must has its unique advantages, thus its future is worth our trust. 


\section{Acknowledgements}

The project of Guangxi center of humanities and social sciences:"Guangxi art and design research team of characteristic industries", contract NO.TD2011011

\section{References:}

[1] YuChangmin.CeramicDiscussion[M]. Shenyang: Liaoning Fine Arts Publishing, PP.55, May2012.

[2]Hu Fuzhao. Pot Universe: Art discussion of Purple Clay Pot [M].Guilin: Guangxi Normal University Press, PP.113, May 2012.

[3]Ning Shaoqiang. Product Image Design $[\mathrm{M}]$.Beijing: Chemical Industry Press, 2008.

[4] Some Advices of Qinzhou Government on Nixing Pottery Develoment[Z], Qinzhou Government(2007)8.

[5] Yu Changmin. Rise and Decline of Nixing Pottery in Qinzhou of Guangxi [M].Ceramic History, January 2007.

[6] Yao Lan. Treasure in the FireCeramic [M], Shanghai Education of Science and Technology press, January 2007. [7]Kenyanhara. Design of Design[M]. Guilin: Guangxi Normal University Press, September2010.

[8] Li Yanzu. Introduction to Industrial Art $[\mathrm{M}]$. China Light Industry Press, May 2005.

[9] Yang Yongshan. Ceramic Discussion [M].Harbin: Heilongjiang Arts Publishing, January 2011.

[10] Xu Xiutang. Purple Clay Craft [M]. Zhejiang People's Publishing, October2009. 